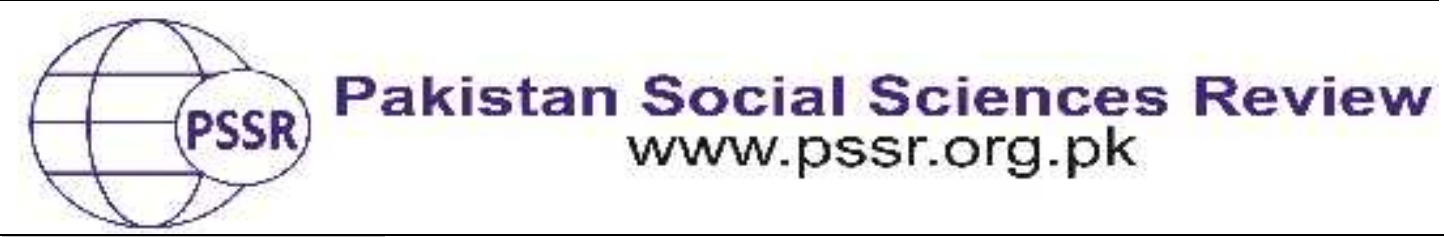

RESEARCH PAPER

\title{
Challenges to Professional Socialization of Female English Teachers in Pakistan
}

\author{
Iqra Arif ${ }^{1}$ Dr. Fakhar Hussain Malik ${ }^{2}$ Dr. Adnan Tahir ${ }^{3}$
}

1. M. Phil Scholar, Department of English, RIPHAH International University, Faisalabad, Punjab, Pakistan

2. Lecturer, Department of English, Languages and Translation Studies, Northern Border University, Saudi Arabia

3. Associate Professor, Department of English, University of Okara, Punjab, Pakistan

\begin{tabular}{|c|c|}
\hline PAPER INFO & ABSTRACT \\
\hline $\begin{array}{l}\text { Received: } \\
\text { June } 02,2020 \\
\text { Accepted: } \\
\text { August } 25,2020 \\
\text { Online: } \\
\text { September } 15,2020 \\
\end{array}$ & $\begin{array}{l}\text { The purpose of this study is to know the professional } \\
\text { socialization challenges with which female English teachers are } \\
\text { confronted in their schools during the initial stage of their } \\
\text { career. The data was collected through survey method by using } \\
\text { questionnaires and afterwards qualitative interpretation of the }\end{array}$ \\
\hline $\begin{array}{l}\text { Keywords: } \\
\text { Classroom } \\
\text { Management, } \\
\text { Professional } \\
\text { Socialization, } \\
\text { Workplace } \\
\text { Learning }\end{array}$ & $\begin{array}{l}\text { stratified sampling technique was used for choo } \\
\text { teachers from } 35 \text { schools located in the district; Shei } \\
\text { The study has found many personal and organ } \\
\text { challenges including the lack of professional trainings } \\
\text { insufficient trainings programs, deficiency of expert m } \\
\text { staff, and lack of seniors' support, lack of facilitie }\end{array}$ \\
\hline $\begin{array}{l}\text { Corresponding } \\
\text { Author }\end{array}$ & $\begin{array}{l}\text { organization and low level of job satisfaction. It is anticipated } \\
\text { that the research findings would support the future researchers } \\
\text { in understanding the complex system of professional } \\
\text { socialization of teachers of English language in Pakistan }\end{array}$ \\
\hline
\end{tabular}

Introduction

The objective of this study was to investigate those English language teaching practices in which female teachers are professionally socialized. Through this investigation, this study aims at finding out the socialization challenges of female teachers during teaching of English and the other adjustments they have to make in an organization especially when they are newly appointed at workplace. This study shows unsatisfactory condition of teachers' professional socialization which is only confined to the traditional trainings before joining the schools and after joining limited refresher courses. It is also revealed from this study that there are many problems at the workplace from which the female teachers have to go through while performing their jobs. Many female English teachers feel reservations on the actual working of those training lessons which they are taught during the training. 


\section{Literature Review}

\section{Organizational socialization practices of female English teachers}

This study understands professional socialization as a complex process in which female teachers go through different teaching trainings workshops and their own perceptions about ongoing teaching experiences. From the previous studies, it appears that through professional socialization a person becomes able to cope with professional merits, norms and restrictions of culture where he or she works (Eder, 1995).The established culture of an organization makes them experienced to follow the rules in performing their tasks. Peters and Waterman (1982) make the attention focused on cultural significance which is very important in getting high place for organizational achievement. There is a significant relationship among organizational leadership, professional collaboration, and teachers' job satisfaction (Torres, 2019).Mostly research in this area has been done in the perspective of socialization of fresh appointed teachers, i.e., beginning teacher socialization. In the overall teaching period, there is found continuous change in the roles and responsibilities. The extensive study of literature by Clausen (1968) and Danziger (1971) relate the term with their contemporary background to Park (1939), Dollard (1939), who used nearly similar terms in sociology (study of society), and psychology (human's behaviour).

\section{Organizational Culture}

To get adjustment in organizational culture, female teachers adopt cultural setting, set standards and customs of the organization for their profession. From the previous view of study by Handy (1993), it is revealed that organizations assign various tasks and job responsibilities which demand professional ability and competence. However, it is significant to know that professional agency has main role in understanding teacher professional development is the organizational context (Kauppinen, Kainulainen, Hökkä \& Vähäsantanen 2020). However, the agency develops over a period of time in one's professional career and it is achieved after an accumulation of positive outcomes (Bartell, Cho, Drake, Petchauer \& Richmond, 2019). In Pakistani culture, the gender variation may be referred as gender inequity which can be very clearly seen in every social, economic and political background. In the previous studies, this type of gender difference can be viewed as an obvious clue of gender bias in the classified culture (King\& Mason, 2001).In this perspective, Weiler (1988)records that the unimportant changes coupled to gender generally create alternative ways which develop several problems of males and females' interactions.

\section{Various phases in organizational enculturation}

According to Cherubini (2009), studies from 1960 to 1980s, mostly kept the newly reviewed teachers' enculturation and socialization within organizational culture in focus. According to Fuller and Brown (1975),from female teachers' perspectives, there are different phases to make improvement as professional teachers. Ryan's (1986) study (as cited in Iqbal, 2017) records an order of various 
steps in beginning teachers' professional socialization. In connection of the previous study, the primary phase is a time for female teachers to start their job with a struggle by accepting the established norms and values of the very organization where they initiate their profession. The second phase is the time for female teachers to accept and adjust themselves or violate the set standards and organizational values. In recent studies in the local context, many issues are assessed like religious, political, local and educational to teaching of English in Pakistan. In reference of previous studies (Mirza, 2009; Rahman, 2009; Mansoor, 2009), there are many barriers in the effective professional socialization of teachers, such as old teaching methods, insufficiency of staff, stereo typical teaching practices, vague curriculum, lack of mentoring, changing national policies and above all the lacking teaching resources.

\section{Material and Methods}

\section{Research design}

The present study is based on descriptive and statistical data. This study is mainly confined to the survey method, i.e., questionnaires. The data was gathered with such techniques that could be helpful in describing and quantifying also. The main concern of the researchers was to realize the challenges and problems related with learning in profession and to identify the problems in the way of professional development. However, the study followed mainly quantitative analysis followed by qualitative interpretation where needed.

\section{Sampling}

The study has used probability sampling approach by giving equal opportunity and chance to every participant from the population of female English teachers of district Sheikhupura, Punjab, Pakistan. Specifically, the stratified random sample technique was employed to ensure the true representation from every stratum of the population. In population of this study, there were three stratums from which significant participants were selected.

Table1

Stratified Sampling

\begin{tabular}{ccc}
\hline Geography & Institution type & Job status \\
\hline Urban & Public & Permanent / Regular \\
$\&$ & $\&$ & $\&$ \\
Rural & Private & Contract /Visiting \\
\hline
\end{tabular}

For required data collection, the sample of overall 100 female English teachers working on permanent or contract basis at primary level to high school level from 35 public and private, urban and rural schools of district Sheikhupura participated in this study. 


\section{Piloting the questionnaire}

For the present study, use of cross-sectional survey proved helpful in collecting and analyzing data within short time. According to the view of Cooper \& Schiknle (2006), such cross-sectional survey designs are typically useful for data collection from a population at a limited position. A generalized view of masses is obtained in this survey design at some definite moment for preferences about facts across a wide population. A comprehensive list of the questions was prepared to collect the required data. The statements were either borrowed or generated after passing them through validity checks of consulting the experts and piloting the questionnaire. The questions were then modified and adapted according to the suggestions and comments of the pilot study respondents, total 15 in number. Particularly, following the instructions of Cooper and Schindler (2006) and Jean and Presser (1986), the appropriate restricted wording was used for constructing and presenting the collective view. The questionnaire was mainly designed to obtain information related to the problems and challenges of female English teachers at their workplace. The questionnaire for this study was adapted and taken from the previous similar study conducted in the Pakistani context by Tahir and Qadir (2012) and Tahir, Akhter and Qureshi (2018). The study has used the Likert scale by providing the respondents with six options ranging from Disagree Strongly to Agree Strongly.

$\begin{array}{ll}\text { Range } & \text { Interpretation } \\ 0.00-1.00 & \text { Disagree Strongly } \\ 1.01-2.00 & \text { Disagree } \\ 2.01-3.00 & \text { Disagree Slightly } \\ 3.01-4.00 & \text { Agree Slightly } \\ 4.01-5.00 & \text { Agree } \\ 5.01-6.00 & \text { Agree Strongly }\end{array}$

\section{Results and Discussions}

\section{Response frequency related to professional learning}

In Table 1, the collected data is described in a very manageable from by displaying its frequencies to give an output of the information. This table shows the frequency of various items with composite variable of professional learning. The left side of the column, name as Domain/Item, consists of a valid subject or statement about the mentioned issue regarding professional learning in very first part of the questionnaire. In the next (second) column, named as Response, different items, offered to the respondents, are demonstrated in the table and complete choices mentioned in the questionnaires are also written in this column. In the next column of Frequency, the respondents' rate who replied for the option they selected is mentioned. The next column of Percent shows the overall statistics of percentage of participants' response for the particular choice is shown. For instance, Question No. 1 , mentioned in the Table 1 is about professional development; it can be seen that a 
great number of participants, i.e., 53.0\%, chose Disagree Strongly that suggests the idea bout lacking knowledge of English subject particularly from the institution where they work. Respectively, $21.0 \%$ went for Disagree option that also indicates the same condition, aforementioned, even with minimum number. Likewise, the percentage for the option of Disagree Slightly remained only $6.0 \%$ that reflect the instructional capability of participants related to their subject. The response rate was $7.0 \%$ from the participants in choice of Agree, which indicated the least number of occurrences in the given table while participating respondents appeared in this study having the percentage number of $8.0 \%$ was in favour of Agree Strongly for having adequate subject related knowledge from their schools. In the table, the sum of $100 \%$ values is also shown at the end. In these results, the series mean replaced the missing values; hence the columns showing the missing values and valid percent were not included here. The last column of the Table 1 is very significant as it shows the cumulative percent. For instance, the item/ question no. 1, consists of compound variable of professional learning table explicates that $53.0 \%$ respondents selected Disagree Strongly that shows the idea of having not enough knowledge about the subjects or subject related instructions were not given to them. Similarly, $74.0 \%$ respondents respond for Disagree with choice of Disagree Strongly that expressed the similar situation of having inadequate institutional training for the subject that is the actual issue to be noticed. The $80.0 \%$ people participating in this study respond with the choices of Disagree Slightly, Disagree Strongly, and Disagree, from which it is clear that insufficient professional training and lacking subject knowledge are considerable issues. Correspondingly $87.0 \%$ participating teachers in this study opted for Slightly Agree with addition Disagree Strongly, Disagree and Disagree Slightly that appears the low rate of respondents $(7.0 \%)$ for having training as professionals and subject relating knowledge is issue for professional socialization. The rates showed that $92.0 \%$ respondents opted for agree by including choices of Disagree Strongly, Disagree, Disagree Slightly which reflects the thought same as described above. Overall, for the response for this questions show that majority of the participants think to have no subject training in an adequate manner, so it is also one of issues in effective socialization for female English teachers during their profession while some of them think to have sufficient subject training which not an issue is for them in socializing themselves.

Table 1

Frequency statistics of respondents' response about professional learning

\begin{tabular}{ccccc}
\hline Item/ Domain & Response & F & Percent & Cumulative \% \\
\hline & Disagree Strongly & 53 & 53.0 & 53.0 \\
\cline { 2 - 5 } & Disagree & 21 & 21.0 & 74.0 \\
\cline { 2 - 5 } & Disagree Slightly & 6 & 6.0 & 80.0 \\
\cline { 2 - 5 } $\begin{array}{c}\text { Sufficient subject training } \\
\text { Subject training from } \\
\text { department }\end{array}$ & Agree Slightly & 7 & 7.0 & 87.0 \\
\cline { 2 - 5 } & Agree & 5 & 5.0 & 92.0 \\
\cline { 2 - 5 } & Agree Strongly & 8 & 8.0 & 100.0 \\
\cline { 2 - 5 } & Total & 100.0 & 100.0 & \\
\hline Syllabus guidelines & Disagree Strongly & 20 & 20.0 & 20.0 \\
\hline
\end{tabular}




\begin{tabular}{|c|c|c|c|c|}
\hline \multirow{6}{*}{$\begin{array}{l}\text { Knowledge of syllabus } \\
\text { significance }\end{array}$} & Disagree & 34 & 34.0 & 54.0 \\
\hline & Disagree Slightly & 22 & 22.0 & 76.0 \\
\hline & Agree Slightly & 12 & 12.0 & 88.0 \\
\hline & Agree & 6 & 6.0 & 94.0 \\
\hline & Agree Strongly & 6 & 6.0 & 100.0 \\
\hline & Total & 100.0 & 100.0 & \\
\hline \multirow{7}{*}{$\begin{array}{c}\text { Time for material preparation } \\
\text { Sufficient time for class } \\
\text { preparation }\end{array}$} & Disagree Strongly & 10 & 10.0 & 10.0 \\
\hline & Disagree & 32 & 32.0 & 42.0 \\
\hline & Disagree Slightly & 23 & 23.0 & 65.0 \\
\hline & Agree Slightly & 18 & 18.0 & 83.0 \\
\hline & Agree & 13 & 13.0 & 96.0 \\
\hline & Agree Strongly & 4 & 4.0 & 100.0 \\
\hline & Total & 100.0 & 100.0 & \\
\hline \multirow{7}{*}{$\begin{array}{l}\text { Opportunity for learning } \\
\text { Learning activities for } \\
\text { profession }\end{array}$} & Disagree Strongly & 14 & 14.0 & 14.0 \\
\hline & Disagree & 11 & 11.0 & 25.0 \\
\hline & Disagree Slightly & 30 & 30.0 & 55.0 \\
\hline & Agree Slightly & 26 & 26.0 & 81.0 \\
\hline & Agree & 12 & 12.0 & 93.0 \\
\hline & Agree Strongly & 7 & 7.0 & 100.0 \\
\hline & Total & 100.0 & 100.0 & \\
\hline \multirow{7}{*}{$\begin{array}{l}\text { Teaching aids } \\
\text { Availability of teaching aids }\end{array}$} & Disagree Strongly & 20 & 20.0 & 20.0 \\
\hline & Disagree & 14 & 14.0 & 34.0 \\
\hline & Disagree Slightly & 17 & 17.0 & 51.0 \\
\hline & Agree Slightly & 26 & 26.0 & 77.0 \\
\hline & Agree & 12 & 12.0 & 89.0 \\
\hline & Agree Strongly & 11 & 11.0 & 100.0 \\
\hline & Total & 100.0 & 100.0 & \\
\hline
\end{tabular}

\section{Univariate analysis: Data description for professional learning}

It appears in items (Table 2), that the mean, median and mode seem reasonable according to the standards of normality. The data clearly reflects that all the means and other required values were found within the normal range, corresponding with the values presented in the codebook. Likewise, the maximum and minimum values were also found with prescribed ranges and none was found lesser or higher beyond expectation. Realistically, in data no errors were found.

Table 2

Univariate analysis for professional learning

\begin{tabular}{cccccc}
\hline Subject training & $\begin{array}{c}\text { Syllabus } \\
\text { guidelines }\end{array}$ & $\begin{array}{c}\text { Time for } \\
\text { material } \\
\text { preparation }\end{array}$ & $\begin{array}{c}\text { Availability } \\
\text { of } \\
\text { professional } \\
\text { learning }\end{array}$ & $\begin{array}{c}\text { Institutional } \\
\text { teaching } \\
\text { aids facility }\end{array}$ \\
\hline Missing & 100 & 100 & 100 & 100 & 100 \\
\hline
\end{tabular}




\begin{tabular}{cccccc}
\hline Mean & 2.14 & 2.68 & 3.04 & 3.32 & 3.29 \\
\hline Standard Error & 0.16 & 0.13 & 0.13 & 0.13 & 0.16 \\
\hline Median & 1.0 & 2.0 & 3.0 & 3.0 & 3.0 \\
\hline Mode & 1.0 & 2.0 & 2.0 & 3.0 & 4.0 \\
\hline Std. Deviation & 1.61 & 1.39 & 1.34 & 1.39 & 1.61 \\
\hline Skewness & 1.34 & 0.81 & 0.41 & -0.04 & 0.04 \\
\hline Range & 5.0 & 5.0 & 5.0 & 5.0 & 5.0 \\
\hline Minimum & 1.0 & 1.0 & 1.0 & 1.0 & 1.0 \\
\hline Maximum & 6.0 & 6.0 & 6.0 & 6.0 & 6.0 \\
\hline Sum & 214 & 268 & 304 & 332 & 329 \\
\hline
\end{tabular}

\section{Response frequency table for classroom management}

Composite variable of classroom management with representation of frequencies for items is described in the Table 3.It was described in the same way as earlier in Table 1. Such as, for the given item/ question 1, stated in the Table 3, 39.0\% from overall sample of study, selected an option for Disagree Strongly in general about the opinion of classroom controlling comfort. Similarly, $21.0 \%$ members of the participant group, gave their opinion for Disagree, by representing same situation, described before this with little difference. The participants with frequency of $9.0 \%$ picked option for Disagree Slightly that exclusively shows that, in general, female teachers were not worried about the control of their classes. In favour of Slightly Agree, 12\% from all the participants favoured this particular choice, so in analyzing this choice, it is the perception of the participants that in managing a class no issue was found generally. The members who considered there were no problems regarding class handling and felt themselves comfortable with it were $12 \%$ by showing their choice in form of Agree. Only 7\% of the whole sample replied for Agree Strongly as they think to be comfortable in management and instruction of class that is not considered an issue for English teachers usually. Finally, the total calculations of given choices have been described in the Table 2as 100\%.The column termed as valid percent reveals missing values regarding collection of the data. Similarly, the last column is of great importance due to its frequency separation from other column types. For instance, it is disclosed that $39 \%$ participants selected an option of Disagree Strongly which showed their worry in handling classroom issues during teaching their subject. It is not a comfort point for them as they feel themselves in trouble to manage a large number of students. Equally the previous choice $60 \%$ respondents replied in inclusion of options Disagree and Disagree Strongly, from this calculation of the participants it has become an obvious point that in most cases female English teachers find themselves anxious in class managing matters which is not a comfortable situation for them; rather it is an issue to be dealt seriously. Likewise, 69\% members chose the options consisted of Disagree Slightly with Disagree Strongly and Disagree. In the next observation, $81 \%$ respondents were found in support of the subsequent choices by adding Slightly Agree, Disagree Strongly, Disagree, Disagree Slightly; respondents' answer in statement of classroom comfort was less with number of $12 \%$ only. In other case, $93 \%$ of the participants of the study replied for 
the choice described in provided questionnaires to the respondents by selecting Agree, Disagree Strongly, Disagree, Disagree Slightly and Slightly Agree.

Table3

Frequency statistics of respondents' response about classroom management

\begin{tabular}{|c|c|c|c|c|}
\hline Domain/Item & Response & Frequency & Percent & lative Percer \\
\hline \multirow{7}{*}{$\begin{array}{c}\text { Handling classroom } \\
\text { Comfort with class } \\
\text { managing }\end{array}$} & Disagree Strongly & 39 & 39.0 & 39.0 \\
\hline & Disagree & 21 & 21.0 & 60.0 \\
\hline & Disagree Slightly & 9 & 9.0 & 69.0 \\
\hline & Agree Slightly & 12 & 12.0 & 81.0 \\
\hline & Agree & 12 & 12.0 & 93.0 \\
\hline & Agree Strongly & 7 & 7.0 & 100.0 \\
\hline & Total & 100.0 & 100.0 & \\
\hline \multirow{7}{*}{$\begin{array}{l}\text { Classroom worry } \\
\text { Issue in class control }\end{array}$} & Disagree Strongly & 14.0 & 14.0 & 14.0 \\
\hline & Disagree & 40.0 & 40.0 & 54.0 \\
\hline & Disagree Slightly & 22.0 & 22.0 & 76.0 \\
\hline & Agree Slightly & 14.0 & 14.0 & 90.0 \\
\hline & Agree & 8.0 & 8.0 & 98.0 \\
\hline & Agree Strongly & 2.0 & 2.0 & 100.0 \\
\hline & Total & 100.0 & 100.0 & \\
\hline \multirow{7}{*}{$\begin{array}{c}\text { Students' } \\
\text { understanding } \\
\text { Easy to deal } \\
\text { individuals }\end{array}$} & Disagree Strongly & 7.0 & 7.0 & 7.0 \\
\hline & Disagree & 17.0 & 17.0 & 24.0 \\
\hline & Disagree Slightly & 37.0 & 37.0 & 61.0 \\
\hline & Agree Slightly & 21.0 & 21.0 & 82.0 \\
\hline & Agree & 15.0 & 15.0 & 97.0 \\
\hline & Agree Strongly & 3.0 & 3.0 & 100.0 \\
\hline & Total & 100.0 & 100.0 & \\
\hline \multirow{7}{*}{$\begin{array}{c}\text { Students' control } \\
\text { Disciplinary measure }\end{array}$} & Disagree Strongly & 7.0 & 7.0 & 7.0 \\
\hline & Disagree & 15.0 & 15.0 & 22.0 \\
\hline & Disagree Slightly & 25.0 & 25.0 & 47.0 \\
\hline & Agree Slightly & 24.0 & 24.0 & 71.0 \\
\hline & Agree & 20.0 & 20.0 & 91.0 \\
\hline & Agree Strongly & 9.0 & 9.0 & 100.0 \\
\hline & Total & 100.0 & 100.0 & \\
\hline Less involvement & Disagree Strongly & 3.0 & 3.0 & 3.0 \\
\hline \multirow{6}{*}{ Lacking attention } & Disagree & 17.0 & 17.0 & 20.0 \\
\hline & Disagree Slightly & 20.0 & 20.0 & 40.0 \\
\hline & Agree Slightly & 28.0 & 28.0 & 68.0 \\
\hline & Agree & 19.0 & 19.0 & 87.0 \\
\hline & Agree Strongly & 13.0 & 13.0 & 100.0 \\
\hline & Total & 100.0 & 100.0 & \\
\hline
\end{tabular}




\section{Univariate analysis: Data description for professional learning}

It appears in items (Table 4), that the mean, median and mode seem reasonable according to the standards of normality. The data clearly reflects that all the means and other required values were found with the normal range, corresponding with the values presented in the codebook. Likewise, the maximum and minimum values were also found with prescribed ranges and none was found lesser or higher beyond expectation. Realistically, in data no errors were found.

Table 4

Univariate analysis of classroom management

\begin{tabular}{cccccc}
\hline & $\begin{array}{c}\text { Managing } \\
\text { classroom }\end{array}$ & $\begin{array}{c}\text { Classroom } \\
\text { anxiety }\end{array}$ & $\begin{array}{c}\text { Individuals' } \\
\text { understanding }\end{array}$ & $\begin{array}{c}\text { Students' } \\
\text { controlling } \\
\text { action }\end{array}$ & $\begin{array}{c}\text { Students' } \\
\text { lack of } \\
\text { involvement }\end{array}$ \\
\hline $\mathrm{N}$ & 100 & 100 & 100 & 100 & 100 \\
\hline Missing & 0 & 0 & 0 & 0 & 0 \\
\hline Mean & 2.58 & 2.68 & 3.29 & 3.61 & 3.82 \\
\hline Standard Error & 0.168 & 0.122 & 0.120 & 0.141 & 0.135 \\
\hline Median & 2.0 & 2.0 & 3.0 & 4.0 & 4.0 \\
\hline Mode & 1.0 & 2.0 & 3.0 & 3.0 & 4.0 \\
\hline Std. Deviation & 1.688 & 1.229 & 1.208 & 1.413 & 1.358 \\
\hline Skewness & 0.700 & 0.703 & 0.121 & -0.064 & -0.060 \\
\hline Range & 5.0 & 5.0 & 5.0 & 5.0 & 5.0 \\
\hline Minimum & 1.0 & 1.0 & 1.0 & 1.0 & 1.0 \\
\hline Maximum & 6.0 & 6.0 & 6.0 & 6.0 & 6.0 \\
\hline Sum & 258 & 268 & 329 & 361 & 382 \\
\hline
\end{tabular}

\section{General Findings}

Overall, the data has found a good degree of satisfaction of female English teachers; however, many predictors of challenges to the professional development of these teachers were explored in detailed analysis. These challenges were mainly related with professional learning, management of classroom, adjustment to the organization's environment. So, in terms of declared objectives, the present study has been accomplished in an effective way with justification of the answers for the study objectives by presenting reasons for not being satisfied with workplace professionalism of female English teachers.

\section{Predictors of Challenges to Professional Learning}

The present study has highlighted the issues of learning with professional understanding of female English teachers for developing themselves at workplace.

In association with the enquiry about professional learning, the study results about achieving subject related knowledge have found its effects on their ongoing process of professional socialization. In this regard, statement/question, "You were 
given necessary guidance from your sector to have adequate understanding in English subject that you teach" exposes that the $80 \%$ of research sample repudiates this statement as they were not provided enough instructional content relevant to their subject by their department. From the entire sample, only 20\% teachers have entertained this statement by favouring (Table1).

Similarly, another indicator of challenges to professional learning appears which is related to the less familiarity of female English teachers with specific parts of syllabus they need to stress on. In response to the question/statement, "You have been educated properly which parts of the syllabus need to be more focused", $74 \%$ of the total participants showed their refusal for having instructions about syllabus specification during their training process, which may be interpreted as discouraging situation for them during socializing themselves in teaching profession. The rest $26 \%$ of the teachers expressed to have knowledge which parts of syllabus they need to focus (Table1).

\section{Predictors of challenges to classroom management}

The classroom management is the vital content of professional socialization of teachers whereby they pass through various classroom related problems or challenges. Therefore, it has been viewed as an important objective for this study.

The results with reference to the question/statement reveal a general condition of distress among female teachers about managing class in a good way. In response to the statement, "You think comfortable yourself with your classroom management and control in general", a majority of the participants, $69 \%$ showed to have problems in managing and controlling classroom generally that affect their adjustment in professional socialization. On the other hand, the remaining 31\% participants have not shown any concern or trouble in the control or management of classroom which may affect their professional practices (Table 3).

Likewise, another observation of the statement/ question, "You remain disturbed about the control of classroom", it is declared that the $76 \%$ participants were found confused about their class control. They feel themselves uncomfortable and worried about it particularly at that time in the beginning years of their career. The rest of the participants, $24 \%$ felt neither anxiety nor any disturbance regarding this matter. They feel it not a big deal to manage a class, so they feel it does not have any negative influence on their socialization in usual. (Table3)

\section{Conclusion}

The process of professional socialization of female teachers is very complex which comprises so many pre-service and in-service off-the-job and on-the-job trainings and workplace mentoring. This process is directly or indirectly influenced by teachers' self-perception, their level of job satisfaction and self-efficacy, role of peers and senior colleagues, administrative authorities and so many other personal and structural factors. The study has explored how various kinds of structural 
(organizational) problems at school level describe the professional socialization of female English teachers. Likewise, the study has also highlighted the personal perceptions of female English teachers to know how these affect their professional behaviors. Expanding the idea of professional socialization, the study targeted specifically to identify the teaching and the classroom management associated problems of female English teachers and the actions through which their effectiveness of socialization is affected. The study has presented a good picture of female English teachers' professional knowledge during instructional teaching programs and their contributions to make the professional socialization process successful. This study would help female English teachers, the authorities concerned and other educationist in general in understanding the process of professional socialization and how the provoking challenges be tackled effectively to improve female teachers' performance, professional learning and overall job satisfaction.

\section{Recommendations}

In this context, the study suggests enhancing female English teachers' learning of profession through some distance learning programs which may be provided to them as it is found difficult for female teachers to go from their places of posting. It can enhance their knowledge about that specific subject they teach. To make professional purposes fruitful, it is significant to make the syllabus for training workshops according to the actual classroom environment and needs of the teachers as well as of students. The issues or problems at interactional level need to be tackled through teachers' professional improvement. Some reward programs or incentives can be introduced for best performance of teachers in their real-life classroom environment. 


\section{References}

Bartell, T.,Cho, C., Drake,C., Petchauer,E., \& Richmond, G. (2019). Teacher agency and resilience in the age of neoliberalism [Editorial]. Journal of Teacher Education, 70(4), 302-305. DOI:10.1177/0022487119865216

Cherubini, L. (2009). Reconciling the tensions of new teachers' socialization into school culture: A review of the research. Issues in Educational Research, 19(2).

Clausen, J. A. (1968). Socialization and society. Little, Brown.

Cooper, D. R., Schindler, P. S. \& Sun, J. (2006). Business research methods, (9). New York: McGraw-Hill Irwin.

Danziger, K. (1971). Socialization. London: Penguin

Dollard, J. (1939). Culture, society, impulse, and socialization. American Journal of Sociology, 45(1), 50-63.

Eder, D. (1995). School talk: Gender and adolescent culture. Rutgers University Press, Livingston Campus.

Fuller, F. \&Bown, O. (1975). Becoming a teacher. In K. Ryan (ed.),Teacher education (74th Yearbook of the National Society for theStudy of Education. Part 2)(pp. 2552). Chicago:University ofChicago Press.

Handy, C. (1993). Understanding organizations (4th ed.). London-UK, Penguin Books Ltd.

Iqbal, A. (2017). Organizational challenges to formal and informal professional socialization of beginning English teachers. Master thesis submitted in Riphah International University, Faisalabad, Pakistan.

King, E. M. \& Mason, A. D. (2001). Engendering development through gender equality in rights resources and voice. World Bank Policy Research Report 21776. Washington, DC: World Bank.

Kauppinen, M., Kainulainen, J., Hökkä, P., \&Vähäsantanen, K. (2020). Professional agency and its features in supporting teachers' learning during an in-service education programme. European Journal of Teacher Education, 43(3), 384-404. DOI. $10.1080 / 02619768.2020 .1746264$

Mansoor, S. (2009). Regional languages of Pakistan: Issues and concerns for language planning in Higher Education. In S. Mansoor, A. Skiandar, N. Hussain, \&N.M. Ahsan (Eds.), Emerging issues in TEFL: Challenges for Asia (pp. 31-58). Karachi: Oxford University Press.

Mirza, N. (2009). Mentoring: A concept for teacher development. In S. Mansoor, A. 
Skiandar, N. Hussain, \& N.M. Ahsan (Eds.), Emerging issues in TEFL: Challenges for Asia (pp. 207-230). Karachi: Oxford University Press.

Park, R. E. (1939). Symbiosis and socialization: A frame of reference for the study of society. American Journal of Sociology, 45(1), 1-25.

Peters, T. J., Waterman, R. H. \& Jones, I. (1982). In search of excellence: Lessons from America's best-run companies. New York: HarperCollins.

Rehman, T. (2009). Language policy, language death and vitality in Pakistan. In S. Mansoor, A. Skiandar, N. Hussain, \& N.M. Ahsan (Eds.), Emerging issues in TEFL: Challenges for Asia (pp. 3-30). Karachi: Oxford University Press.

Ryan, K. (1986). The induction of new teachers: The social organization of schools. New York: Longman.

Tahir, A. \& Qadir, S. A. (2012). Challenges of classroom management to effective teacher socialization: A study of beginning English teachers. Pakistan Journal of Social Sciences, 32(1), 21-37.

Tahir, A., Iqbal, A., Qureshi, A.H. (2018). Classroom management: A challenging part in beginning English teachers' career entry stage. International Journal of English Linguistics, 8(4), 155-163.

Torres, D.G. (2019). Distributed leadership, professional collaboration, and teachers'job satisfaction in U.S. schools. Teaching and Teacher Education, 79, 111123. DOI: $10.1016 /$ j.tate.2018.12.001

Weiler, K. (1988). Women teaching for change: Gender, class \& power. Greenwood Publishing Group. 